\title{
Pengenalan Wajah dengan Matriks Kookurensi Aras Keabuan dan Jaringan Syaraf Tiruan Probabilistik
}

\author{
Toni Wijanarko Adi Putra ${ }^{\mathrm{a},}{ }^{,}, K$ Kusworo Adi ${ }^{\mathrm{b}}$, R. Rizal Isnanto ${ }^{\mathrm{c}}$ \\ ${ }^{a}$ Mahasiswa Magister Sistem Informasi Universitas Diponegoro \\ ${ }^{\mathrm{b}}$ Program Studi Fisika, Fakltas Sains dan Matematika, Universitas Diponegoro \\ ${ }^{c}$ Program Studi Sistem Komputer, Fakultas Teknik Universitas Diponegoro
}

Naskah Diterima : 12 April 2012; Diterima Publikasi : 2 Juli 2013

\begin{abstract}
Face recognition system is a development of the basic methods of authentication system using the natural characteristics of the human face as a baseline. Face recognition process consists of several phases, training and testing phase. The testing phase is done directly and indirectly. Indirect data test taken from a set of face images that have been selected, while direct data test take face image from camera. Human face recognition combines Gray Level Co-Occurrence Matrix/GLCM and Probabilistic Neural Network/PNN methods. Preprocessing is done by converting RGB to grayscale, using centroid method as face image segmentation process. Face recognition includes some factors, i.e. lighting, distance, angle and position. GLCM uses statistic method and second-order texture analysis, which represents image texture in following parameters energy, corelation, homogenity and contrast. While PNN is used to build database which is stored in the network in order to compare outcome from GLM in the form of matrix. This research uses face image as database by collecting sample of 10 persons, 5 face position, 2 type of distance shooting and 3 type of lighting. Testing process results $92 \%$ in direct recognition and $93,33 \%$ in inderict recognition.
\end{abstract}

Keywords: GLCM; PNN; Centroid; Preprocesing

\begin{abstract}
Abstrak
Sistem pengenalan wajah merupakan pengembangan metode dasar sistem autentifikasi dengan menggunakan karakteristik alami wajah manusia sebagai dasarnya. Proses pengenalan citra wajah ini melalui beberapa tahap yaitu tahap pelatihan dan tahap pengujian. Pada tahap pengujian dilakukan secara langsung dan tidak langsung. Secara tidak langsung data uji bersumber dari sekumpulan citra wajah yang sudah dipilih, sedangkan secara langsung citra wajah bersumber dari kamera. Pengenalan citra wajah manusia menggunakan penggabungan antara metode GLCM dan PNN. Tahap prapengolahan dengan merubah RGB ke dalam aras keabuan dengan metode centroid sebagai proses segmentasi citra wajah. Faktor pengenalan wajah yang diuji meliputi pencahayaan, jarak, sudut serta posisi. Pada GLCM menggunakan metode statistik dan analisis tekstur orde kedua karena merepresentasikan tekstur citra dalam parameter energi, korelasi, homogenitas dan kontras. Sedangkan PNN digunakan untuk pembentukan basisdata yang disimpan dalam jaringan untuk proses membandingkan hasil keluaran yang berupa data matrik hasil dari GLCM. Pada penelitian ini digunakan citra wajah sebagai basisdata dengan sampel sebanyak 10 orang dan 5 posisi wajah, 2 jarak pengambilan gambar citra wajah, serta 3 kategori pencahayaan. Proses pengujian menghasilkan tingkat pengenalan secara langsung sebesar 92\%, sedangkan pengujian secara tidak langsung sebesar $93,33 \%$.
\end{abstract}

Kata kunci: GLCM; PNN; Centroid; Prapengolahan

\section{Pendahuluan}

Teknologi biometrik mempunyai kemampuan yang cukup baik dibandingkan dengan metode konvensional, terutama dalam hal memproses ciri guna menjadi sangat mudah, selain itu ciri tersebut juga mempunyai keunikan yang melekat pada manusia. Pengembangan teknologi biometrik seperti wajah, suara, iris mata dan sidik jari sudah banyak dikembangkan baik sebagai sistem keamanan maupun sebagai sistem kehadiran. Teknologi biometrik yang sudah berkembang dan diterapkan

*) Penulis korespondensi: t_wijanarko@yahoo.com diberbagai aplikasi tetapi pada kenyataannya proses pengenalan terkadang masih mengalami kegagalan. Beberapa kegagalan diantaranya disebabkan oleh faktor penerangan, jarak objek dengan alat, sudut kemiringan objek terhadap alat, ekspresi serta posisi wajah. Pada penelitian ini dibangun aplikasi untuk mengukur tingkat akurasi pengenalan wajah dengan Matrik Kookuransi Aras Keabuan (Gray Level CoOccurrence Matrix/GLCM) dan Jaringan Syaraf Tiruan Probabilistik (Probabilistic Neural Network/PNN) pada intensitas cahaya, jarak serta sudut yang berbeda. Penelitian ini akan memperbaiki 
kinerja sistem pengenalan wajah agar dapat diaplikasikan di berbagai bidang.

Pengenalan wajah dengan menguji semua frame untuk mengetahui apakah frame tersebut berisikan wajah manusia dan juga mendeteksi citra bergerak dari video dengan menggunakan PNN (Kung, 1999). Pengenalan wajah manusia menggunakan kumpulan citra diam atau video dengan satu set video (Zhou et $a l .$, 2003). Penggunaan video-kamera dan komputer sudah cukup baik untuk memproses video secara waktu-nyata (real-time) (Gorodnichy, 2004).

Pengenalan wajah menggunakan sebuah kamera untuk menangkap wajah seseorang kemudian dibandingkan dengan wajah yang sebelumnya telah disimpan pada basisdata secara waktu nyata (realtime) (Bayu et al., 2009).

Penggunaan GLCM untuk pengambilan citra penginderaan jauh dengan purwarupa (Maheshwary dan Sricastava, 2009). Segmentasi citra untuk menentukan nilai ambang histogram untuk mendapatkan informasi spasial (Nie et al., 2011). Sedangkan penelitian dengan menggabungkan metode GLCM dan PNN dilakukan untuk pengenalan ciri pola benang pada garmen secara otomatis dan deteksi cacat berdasarkan fitur tekstur yang digunakan untuk mendeteksi cacat garmen (Kulkarni dan Patil, 2012).

Sedangkan pada penelitian ini dikembangkan sistem pengenalan wajah secara waktu nyata (realtime) menggunakan video kamera dengan metode GLCM dan PNN. Penelitian tentang pengenalan wajah dengan metode GLCM dan PNN sudah pernah dilakukan, akan tetapi kedua metode tersebut digunakan secara terpisah. Sedangkan penggunaan metode GLCM dan PNN secara bersama sudah dilakukan untuk pengenalan ciri pola benang, dan pada penelitian ini kedua metode tersebut akan digunakan untuk pengenalan wajah. Diharapkan hasil dari penelitian ini didapatkan pengenalan wajah dengan tingkat akurasi yang lebih baik serta didapatkan nilai dari tingkat penerimaan salah dan tingkat penolakan salah pada posisi terendah. Dengan demikian, dari sisi keaslian penelitian (novelty), maka penelitian yang dilakukan ini dapat di pertanggung jawabkan.

\section{Kerangka Teori}

\subsection{Pengenalan Wajah}

Pengenalan wajah dan pengenalan skala citra keabuan secara frontal berdasarkan PNN. Keuntungan dari klasifikasi menggunakan model PNN adalah waktu pelatihan yang singkat. Korelasi berdasarkan template matching menjamin hasil klasifikasi baik (Vinitha, 2009).

Menggambarkan kemungkinan penggunaan berbagai PNN dalam memecahkan beberapa masalah yang timbul dalam pemrosesan sinyal dan pengenalan pola. Hasil penelitian telah dilakukan dan memverifikasi kemampuan PNN dimodifikasi dalam mencapai tingkat klasifikasi yang baik dan dibandingkan dengan PNN tradisional atau BPNN dan BPNN (K Nearest Neighbors/ KNN) (Emary dan Ramakrishnan, 2008).

PNN banyak digunakan dalam masalah teknik dan pengenalan pola pada gangguan tulisan tangan dan skala didasarkan pada (Discrete Cosine Transform/DCT). Hasil simulasi pada basisdata yang sudah ada, menunjukkan bahwa sistem tersebut cukup untuk digunakan sampai ke tingkat kebisingan dan skala tertentu (Sumarno, 2007).

Klasifikasi kapal berdasarkan kovarians wavelet diskret menggunakan PNN, satu set profil kapal yang digunakan untuk membangun sebuah matriks kovarians oleh alihragam wavelet diskret menggunakan Jaringan Syaraf (Araghi et al., 2009).

Model PNN digunakan untuk mendeteksi kerusakan struktural yang dipengaruhi oleh serangkaian faktor, termasuk desain dan konstruksi faktor pipa seperti ukuran pipa, kedalaman dikuburkan dan faktor seperti jenis tanah, kelembaban, intrusi akar pohon, dan lain-lain, penggunaan PNN untuk mengklasifikasikan pola kerusakan yang berbeda pada pipa stormwater (Tran et al., 2006).

Metode GLCM dan PNN digunakan untuk identifikasi cacat garmen secara otomatis dan deteksi cacat berdasarkan fitur tekstur. Model yang diusulkan memberikan hasil kain yang akurat dan klasifikasi cacat. Fitur tekstur yang digunakan untuk mendeteksi cacat garmen ini diklasifikasikan dengan menggunakan classifier PNN. Dengan set kecil pelatihan sampel yaitu 10 untuk masing-masing, keakuratan deteksi garmen cacat dan hasil klasifikasi yang diperoleh PNN lebih baik dari pada BPNN. Juga waktu pelatihan dan waktu klasifikasi yang digunakan oleh PNN kurang dari BPNN (Kulkarni dan Patil, 2012).

\subsection{Sistem Biometrika}

Sistem biometrika merupakan pengembangan dari metode dasar identifikasi dengan menggunakan karakteristik alami manusia sebagai basisnya. Sebelum teknologi biometrika berkembang, pengenalan identitas dilakukan dengan menggunakan metode konvensional. Metode ini masih digunakan secara luas sampai saat ini di berbagai bidang aplikasi. Metode ini memiliki beberapa kelemahan, seperti dapat hilang atau dicuri, dapat terlupa atau dengan menggunakan algoritma bruteforce password seseorang dapat diketahui. Berbagai kelemahan metode konvensional ini menjadi salah satu pemicu berkembangnya sistem biometrika (Falasev et al., 2011).

Biometrika berarti mengukur karakteristik pembeda pada tubuh atau perilaku seseorang yang digunakan untuk melakukan pengenalan secara otomatis terhadap identitas orang tersebut (Maltoni et 
al., 2009). Sistem biometrika pada dasarnya adalah sebuah sistem pengenalan pola yang membuat identifikasi dengan menampilkan keaslian karakteristik secara fisik atau prilaku tertentu yang dimiliki oleh seseorang (Jain et al., 2000).

Biometrika menjadi komponen penting dari solusi identifikasi seseorang, karena pengidentifikasiannya tidak dapat salah dan merupakan keunikan yang mewakili identitas individu. Tujuan pengenalan biometrika adalah kenyamanan, keamanan, akuntabilitas/jaminan atas kebenaran dan efesiensi (Maltoni et al., 2009). Sistem biometrika dinilai dari segi akurasi, kecepatan, dan penyimpanan dan beberapa faktor lain, seperti biaya dan kemudahan penggunaan, juga mempengaruhi keberhasilan (Jain et al., 2000).

Dalam merancang sebuah sistem biometrika yang terpenting adalah bagaimana menentukan seorang individu tersebut dikenali. Proses pengenalan pada sistem biometrika terbagi dalam dua sistem yaitu dengan sistem verifikasi dan sistem identifikasi. Sistem verifikasi merupakan proses mengotentikasi identitas seseorang dengan membandingkan karakteristik biometrika yang diambil sebelumnya dengan template biometrika yang baru diambil. Sedangkan pada sistem identifikasi yaitu mengenali individu dengan mencari template yang terdaftar pada basisdata untuk dibandingkan. Dalam sistem ini dilakukan perbandingan template dari satu kebanyak untuk menetukan apakah individu tersebut ada dalam basisdata, dan sekaligus menentukan bahwa individu tersebut dikenali atau tidak (Maltoni et al., 2009).

Sebuah biometrika yang ideal harus bersifat universal, dimana setiap orang memiliki karakteristik yang unik secara permanen dan tidak ada seorangpun yang memiliki karakteristik yang dipakai secara bersamaan (Jain et al., 2000). Beberapa jenis karakteristik yang digunakan adalah bagian-bagian fisik dari sebagian tubuh seseorang sebagai kode unik untuk pengenalan, seperti DNA, telinga, jejak panas pada wajah, geometri tangan, pembuluh tangan, wajah, sidik jari, iris, telapak tangan, retina, gigi dan bau dari keringat tubuh (Putra, 2009).

\subsection{Pengenalan Pola (Pattern Recognition)}

Pengenalan pola merupakan suatu ilmu untuk mengklasifikasikan atau menggambarkan sesuatu berdasarkan pengukuran kuantitatif ciri atau sifat dari objek (Putra, 2009). Pengenalan suatu objek dengan menggunakan berbagai metode merupakan suatu proses pengenalan pola (Wibowo, 2011).

Secara umum pengenalan pola adalah suatu ilmu untuk mengklasifikasikan atau menggambarkan sesuatu berdasarkan pengukuran kuantitatif fitur (ciri) atau sifat utama dari suatu obyek (Putra, 2010).

Struktur dari sistem pengenalan pola ditunjukkan oleh Gambar 1. Sistem ini terdiri atas sensor (misalnya kamera), suatu algoritma atau mekanisme pencari fitur, dan algoritma untuk klasifikasi atau pengenalan.

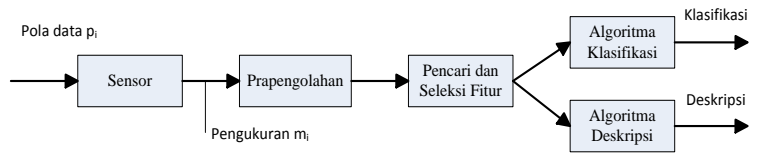

Gambar 1. Struktur sistem pengenalan pola (Putra, 2010)

Berikut ini merupakan bagian-bagian dari sistem pengenalan pola. Sensor untuk menangkap objek nyata yang selanjutnya diubah menjadi sinyal digital melalui proses digitalisasi. Prapengolahan befungsi mempersiapkan citra atau sinyal agar dapat menghasilkan ciri yang lebih baik pada tahap berikutnya. Pada tahap ini citra atau sinyal informasi ditonjolkan dan sinyal pengganggu (derau) dimimalisasi. Pencari dan seleksi ciri berfungsi menemukan karakteristik pembeda yang mewakili sifat utama sinyal dan sekaligus mengurangi dimensi sinyal menjadi sekumpulan bilangan yang lebih sedikit tetapi representatif. Algoritma klasifikasi berfungsi untuk mengelompokkan ciri ke dalam kelas yang sesuai. Algoritma deskripsi berfungsi memberikan deskripsi pada sinyal (Putra, 2010).

Pola adalah komposit/gabungan dari ciri yang merupakan sifat dari sebuah objek. Dalam klasifikasi, pola berupa sepasang variabel $(\chi, \omega)$, dimana $\chi$ adalah sekumpulan pengamatan atau ciri (vektor fitur) dan $\omega$ adalah konsep dibalik pengamatan (label) (Fatta, 2009).

\subsection{Pengenalan Wajah}

Aplikasi pengenalan wajah meliputi pengenalan wajah statis atau terkontrol sampai sistem identifikasi wajah dinamis yang tidak terkontrol di dalam suatu latar belakang yang terbaur (Putra, 2009).

Secara umum sistem pengenalan citra wajah dibagi menjadi 2 jenis, yaitu sistem feature based dan sistem image based. Pada sistem pertama digunakan fitur yang diekstraksi dari komponen citra wajah (mata, hidung, mulu, dan lain-lain) yang kemudian hubungan antara ciri-ciri tersebut dimodelkan secara geometris. Sedangkan sistem kedua menggunakan informasi mentah dari piksel citra yang kemudian direpresentasikan dalam metode tertentu, misalnya Principal Component Analysis (PCA), transformasi wavelt, GLCM yang kemudian digunakan untuk klasifikasi identitas citra (Fatta, 2009).

\subsection{Pengolahan Citra}

Istilah image processing, image analysis, image understanding, dan komputer vision ini sering dijumpai dalam mempelajari pengolahan citra digital. Keempat istilah di atas seringkali dibedakan dari proses masukan dan keluarannya (Putra, 2010).

Image processing memiliki masukan dan keluarannya berupa citra, analisa citra (image analysis) memiliki masukan berupa citra dengan 
keluaran bukan citra akan tetapi berupa hasil pengukuran terhadap citra tersebut, image understanding memiliki masukan berupa citra dengan keluarannya adalah deskripsi tingkat tinggi dari citra tersebut (keluarannya bukan berupa citra), komputer vision bertujuan untuk mengkomputerisasi penglihatan manusia atau dengan kata lain membuat citra digital dari citra sebenarnya (sesuai dengan penglihatan manusia) (Putra, 2010). Tujuan dari pengolahan citra adalah memperbaiki kualitas citra agar mudah dibaca oleh manusia atau komputer, merupakan teknik pengolahan citra dengan mentransformasikan citra menjadi citra lain dan merupakan proses awal dari prapemrosesan (preprocessing) dari komputer vision (Prasetyo, 2011).

\subsection{Pusat Massa (Centroid)}

Pusat massa (Centroid) merupakan suatu posisi pada matrik yang didapat dari nilai tengah atau titik berat dari suatu objek yang melewati proses pelabelan yang merupakan hasil dari proses pengolahan data dengan menggunakan operator fuzzy, dengan rumus matematis sebagai berikut :

$$
R=\frac{\sum_{i=0}^{n} \text { di } \mu_{A}(d i)}{\sum_{i-0}^{n} \mu_{A}(d i)}
$$

di mana :

di : nilai domain ke $\mathrm{i}$

$\mu \mathrm{A}(\mathrm{di})$ : nilai derajat keanggotaan untuk titik domain ke-i (Limanto dan Arief, 2005).

Pusat massa atau sentroid (Centroid) pada umumnya ditemukan dengan menggunakan nilai rerata koordinat setiap piksel yang menyusun objek.

\subsection{Prapengolahan (Preprocessing)}

Prapengolahan merupakan tahap awal dalam pengenalan objek yang merupakan proses penelitian dengan menggabungkan konsep citra digital, pengenalan pola, matematika dan statistik. Pada tahap prapengolahan citra yang ditangkap diolah terlebih dahulu untuk disamakan ukurannya dan diubah kedalam bentuk skala keabuan baik data pelatihan maupun data uji coba (Purnomo, 2010).

Citra warna membutuhkan proses pengolahan yang lebih kompleks dari pada citra biner. Oleh karena itu citra perlu diubah terlebih dahulu menjadi citra biner untuk mempermudah dalam proses pengolahan citra, dimana pada citra biner, batas antara objek dengan latar belakang dapat terlihat jelas (Khrisna, 2011).

Pada umumnya ukuran dari citra dapat direpresentasikan sebagai matriks warna berukuran piksel. Piksel (picture element) adalah bagian terkecil dari suatu citra digital. Berikut proses perubahan dari citra berwarna RGB ke keabuan, dan ke citra biner :

1. Citra berwarna yaitu citra dengan karakteristik warna berdasarkan pada persamaan berikut ini.

$$
I_{R}(x, y), I_{G}(x, y) \text { dan } I_{B}(x, y)
$$

2. Citra keabuan yaitu citra dengan karakteristik warna berdasarkan pada persamaan berikut ini.

$$
I_{(x, y)} \in[0 \ldots 255]
$$

3. Citra biner yaitu citra dengan karakteristik warna berdasarkan pada persamaan berikut ini.

$$
I_{(x, y)} \in\{0,1\}
$$

Konversi citra berwarna RGB ke citra keabuan adalah dengan cara memberikan nilai bobot yang berbeda-beda pada setiap komponen RGB, seperti berdasarkan persamaan berikut ini.

$$
\text { Gray }=(0.3 * r)+(0.5 * g)+(0.2 * b)
$$

dengan :

$\mathrm{r}$ : nilai intensitas warna merah

$\mathrm{g}$ : nilai intensitas warna hijau

$\mathrm{b}$ : nilai intensitas warna biru

Proses pengubahan citra keabuan menjadi citra biner adalah dengan memisahkan dua nilai antara objek dengan latarnya berdasarkan hasil pembandingan terhadap nilai ambang (treshold). Nilai ambang yang digunakan adalah nilai disekitar nilai minimum dan maksimum citra keabuan. Persamaan (6) menunjukkan pemisahan nilai intensitas citra keabuan berdasarkan nilai ambang yang telah ditentukan (Heriana, 2011).

$$
\mathrm{Ko}=\left[\begin{array}{l}
1, \text { jika } K i>\text { nilai ambang dengan }(1=\text { putih }) \\
0 \text {, Lainnya }
\end{array}\right.
$$

\subsection{Ekstraksi Ciri dengan GLCM}

Ekstraksi ciri merupakan langkah awal dalam melakukan klasifikasi dan interpretasi citra. Proses ini berkaitan dengan kuantisasi karakteristik citra ke dalam sekelompok nilai ciri yang sesuai. Analisis tekstur lazim dimanfaatkan sebagai proses antara untuk melakukan klasifikasi dan interpretasi citra. Suatu proses klasifikasi citra berbasis analisis tekstur pada umumnya membutuhkan tahapan ekstraksi ciri, yang dapat terbagi dalam tiga macam metode yaitu metode statistik, metode spektral, metode struktural. Berdasarkan orde statistiknya, analisis tekstur dapat dikategorikan menjadi 3, yaitu Statistik orde-kesatu, Statistik orde-kedua dan Statistik orde-ketiga (Febrianto, 2012).

Ekstraksi ciri statistik orde kedua dilakukan dengan matriks kookurensi, yaitu suatu matriks antara yang merepresentasikan hubungan ketetanggaan antar piksel dalam citra pada berbagai arah orientasi dan jarak spasial (Albregtsen, 2008). Matriks kookurensi merupakan matriks berukuran L x L (L menyatakan banyaknya tingkat keabuan) dengan elemen $\mathrm{P}(\mathrm{x} 1, \mathrm{x} 2)$ yang merupakan distribusi probabilitas bersama (join probability distribution) dari pasangan titik-titik dengan tingkat keabuan $\mathrm{x} 1$ yang berlokasi pada koordinat $(\mathrm{j}, \mathrm{k})$ dengan $\mathrm{x} 2$ yang berlokasi pada koordinat $(\mathrm{m}, \mathrm{n})$. Koordinat pasangan titik-titik tersebut berjarak $r$ dengan sudut $\theta$. Histogram tingkat kedua $\mathrm{P}(\mathrm{x} 1, \mathrm{x} 2)$ dihitung dengan pendekatan sebagai berikut :

$P_{(x 1, x 2)}=\frac{\text { banyaknya pasangan titik-titik dengan tingkat keabuan } \mathrm{x} 1 \mathrm{dan} \times 2}{\text { banyaknya titik pada daerah suatu citra }}$ 
Berikut ini ketentuan untuk hubungan pasangan titik-titik dengan sudut $0^{\circ}, 45^{\circ}, 90^{\circ}$, dan $135^{\circ}$ pada jarak r (Putra, 2009).

$$
\begin{aligned}
& P_{0^{\circ}, r}(x 1, x 2)=\left|\left\{\begin{array}{c}
(j, k),(m, n)) \in R: \\
j-m=0,|k-n|=r \\
f_{j, k}=x 1, f_{m, n}=x 2
\end{array}\right\}\right| \\
& P_{45^{0}, r}(x 1, x 2)=\left|\left\{\begin{array}{c}
((j, k),(m, n)) \in R: \\
(j-m=r,|k-n|=-r) \\
o r(j-m=-r, k-n=r), \\
f_{j, k}=x 1, f_{m, n}=x 2
\end{array}\right\}\right| \\
& \left.P_{90^{\circ}, r}(x 1, x 2)=\mid \begin{array}{c}
((j, k),(m, n)) \in R: \\
|j-m|=r, k-n=0, \\
f_{j, k}=x 1, f_{m, n}=x 2
\end{array}\right\} \mid \\
& P_{135^{0}, r}(x 1, x 2)=\left|\left\{\begin{array}{c}
((j, k),(m, n)) \in R: \\
(j-m=r, k-n=r) \\
o r(j-m=-r, k-n=-r), \\
f_{j, k}=x 1, f_{m, n}=x 2
\end{array}\right\}\right|
\end{aligned}
$$

GLCM adalah suatu matriks yang elemenelemennya merupakan jumlah pasangan piksel yang memiliki tingkat kecerahan tertentu, di mana pasangan piksel itu terpisah dengan jarak d, dan dengan suatu sudut inklinasi $\theta$. Dengan kata lain, matriks kookurensi adalah probabilitas munculnya gray level $\mathrm{i}$ dan $\mathrm{j}$ dari dua piksel yang terpisah pada jarak $\mathrm{d}$ dan sudut $\theta$. Suatu piksel yang bertetangga yang memiliki jarak d diantara keduanya, dapat terletak di delapan arah yang berlainan, hal ini ditunjukkan pada Gambar 2.

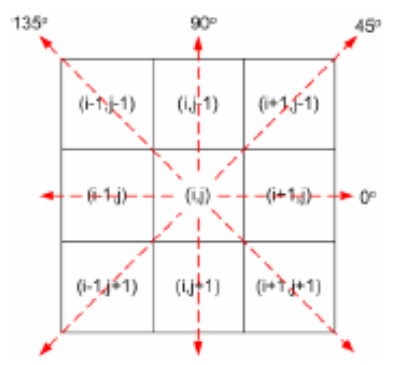

Gambar 2. Hubungan ketetanggaan antar piksel sebagai fungsi orientasi dan jarak spasial (Ganis, 2011)

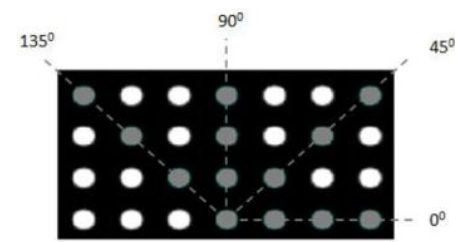

Gambar 3. Arah dalam menghitung GLCM

Arah piksel tetangga untuk mewakili jarak dapat dipilih, misalnya $135^{\circ}, 90^{\circ}, 45^{\circ}, 0^{\circ}$ atau, seperti yang diilustrasikan pada Gambar 3. Sedangkan Gambar 4 menggambarkan bagaimana untuk menghasilkan matriks menggunakan arah $0^{\circ}$ dan dengan jarak 1 piksel.

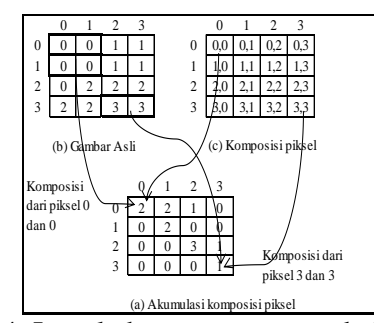

Gambar 4. Langkah pertama mengubah GLCM
Dengan menambahkan transposnya, matriks simetrik akan diperoleh, seperti ditunjukkan pada Gambar 5, tapi hasilnya masih belum ternormalisasi. Oleh karena itu, proses normalisasi harus dilakukan untuk menghapus ketergantungan pada ukuran citra dengan mengatur semua elemen dalam matriks sehingga total dari semua nilai elemen sama dengan 1. Gambar 6 merupakan hasil dari matriks yang telah ternormalisasi.

$$
\begin{aligned}
& {\left[\begin{array}{cccc}
2 & 2 & 1 & 0 \\
0 & 2 & 0 & 0 \\
0 & 0 & 3 & 1 \\
0 & 0 & 0 & 1
\end{array}\right]+\left[\begin{array}{llll}
2 & 0 & 0 & 0 \\
2 & 2 & 0 & 0 \\
1 & 0 & 3 & 0 \\
0 & 0 & 1 & 1
\end{array}\right]=\left[\begin{array}{cccc}
4 & 2 & 1 & 0 \\
2 & 4 & 0 & 0 \\
1 & 0 & 6 & 1 \\
0 & 0 & 1 & 2
\end{array}\right]} \\
& \text { Gambar 5. Prosedure membuat matriks simetrik }
\end{aligned}
$$

$$
\left[\begin{array}{cccc}
\frac{4}{24} & \frac{2}{24} & \frac{1}{24} & \frac{0}{24} \\
\frac{2}{24} & \frac{4}{24} & \frac{0}{24} & \frac{0}{24} \\
\frac{1}{24} & \frac{0}{24} & \frac{6}{24} & \frac{1}{24} \\
\frac{0}{24} & \frac{0}{24} & \frac{1}{24} & \frac{2}{24}
\end{array}\right]
$$

Gambar 6. Matriks ternormalisasi (Kadir et al., 2011)

Ciri statik orde-dua yang merepresentasikan citra wajah diperoleh setelah matriks kookurensinya dapat dihitung. Haralick et al. mengusulkan berbagai jenis ciri tekstur yang dapat diekstraksi dengan matriks kookurensi (Albregtsen, 2008). Beberapa di antaranya adalah sebagai berikut:

1. Momen Angular Kedua (Angular Second Moment)

$$
\mathrm{ASM}=\sum_{i} \sum_{j} P_{d}^{2}(i, j) \quad \text { Energi }=\sqrt{A S M}
$$

2. Entropi (Entropy)

$$
\mathrm{ENT}=-\sum_{i} \sum_{j} P_{d}(i, j) \log \left(P_{d}(i, j)\right)
$$

3. Kontras (Contrast)

$$
\text { CONTRAST }=\sum_{i} \sum_{j}(i-j)^{2} P_{d}(i, j)
$$

4. Korelasi (Correlation)

$$
\mathrm{COR}=\sum_{i} \sum_{j} \frac{i j P_{d}(i, j)-\mu_{x} \mu_{y}}{\sigma_{x} \sigma_{y}}
$$

5. Momentum Selisih Terbalik (Inverse Difference Momentum)

$$
\mathrm{IDM}=\sum_{i} \sum_{j} \frac{1}{1+(i-j)^{2}} P_{d}(i, j)
$$

Sedangkan pada penelitian kali ini hanya menggunakan 4 ciri statistik yaitu kontras, korelasi, energi dan homogenitas. Penggunaan 4 ciri tersebut berdasarkan fungsi yang ada pada program MATLAB yaitu pada graycoprops serta waktu yang dibutuhkan pada saat pelatihan maupun pengujian menjadi lebih cepat karena ciri yang dibandingkan sedikit.

\subsection{Jaringan Syaraf Tiruan Probabilistik}

Pada tahun 1990, Donald F. Specht mengusulkan jaringan yang didasarkan pada pengklasifikasi jarak tetangga terdekat dan menamakannya sebagai 
"Jaringan Syaraf Probabilistik" (Santhanam, 2011). PNN dapat digunakan untuk menyelesaikan masalah klasifikasi (Gill, 2008).

Ketika lapisan pertama diberikan masukan yang menghitung jarak dari vektor masukan terhadap vektor masukan pelatihan, dan menghasilkan vektor yang elemen-elemennya menandakan seberapa dekat masukan terhadap masukan pelatihan. Lapisan kedua menjumlahkan kontribusi ini untuk setiap masukan kelas untuk menghasilkan vektor keluaran jaringan PNN. Fungsi pada lapisan keluaran kedua mengambil probabilitas maksimum dan menghasilkan nilai 1 untuk kelas yang sesuai dan nilai 0 untuk kelas yang tidak sesuai.

PNN dibangun menggunakan ide dari teori probabilitas klasik, seperti pengklasifikasi bayesian (bayesian classification) dan pengestimasian klasik (classical estimator) untuk fungsi kerapatan probabilitas (probability density function), untuk membentuk sebuah jaringan syaraf sebagai pengklasifikasi pola (Harmoko, 2004).

Metode Bayes untuk mengklasifikasikan pola menggunakan suatu aturan pengambilan keputusan yang meminimalkan risiko yang dihadapi. Misalkan terdapat n kelas, $\mathrm{C} 0, \mathrm{C} 1, \mathrm{C} 2, \ldots, \mathrm{Cn}-1$; diasumsikan pola yang diamati adalah variabel acak $\mathrm{x}$ dengan $\mathrm{m}$ dimensi dan fungsi padat peluang bersyarat $\mathrm{x}$, bila diketahui bahwa pola tersebut berasal dari kelas $\mathrm{Ck}$, dinotasikan dengan $p\left(x \mid C_{k}\right)$. Dengan menerapkan aturan pertama dari Bayes, dapat ditulis peluang berikutnya dari variabel x pada kelas $\mathrm{Ck}$ sebagai :

$$
\operatorname{Pr}\left(C_{k} \mid x\right)=\frac{p\left(x \mid C_{k}\right) \operatorname{Pr}\left(C_{k}\right)}{p(x)}
$$

Keputusan dari masalah tersebut dapat diformulasikan dengan cara yang lebih umum untuk meminimalkan resiko yaitu dengan meminimalkan peluang. Aturan keputusan Bayes dalam kasus ini cukup sederhana untuk menentukan kelas $\mathrm{Ck}$, yaitu dengan memilih $\operatorname{Pr}\left(C_{k} \mid x\right)$ yang paling besar, hal ini berarti :

$$
\begin{gathered}
d(x)=C_{k} \quad \text { jika } \\
p\left(x \mid C_{k}\right) \operatorname{Pr}\left(C_{k}\right)>p\left(x \mid C_{j}\right) \operatorname{Pr}\left(C_{j}\right)
\end{gathered}
$$

Model PNN yang dibuat oleh Cain memperbolehkan setiap kelas memiliki parameter penghalus, $\sigma \mathrm{k}$, yang berbeda satu dengan yang lain dan menerapkan algoritma belajar yang baru untuk memperoleh $\sigma \mathrm{k}$ secara otomatis. Apabila tiap kelas memiliki parameter yang memiliki fungsi peluang dapat ditulis sebagai :

$$
p\left(x \mid C_{k}\right)=\frac{1}{(2 \pi)^{\frac{m}{2}} \sigma_{k}^{m}\left|C_{k}\right|} \sum_{\rho_{i} \in C_{k}} \exp \left[-\left\|x-w_{i}\right\|^{2} /\left(2 \sigma_{k}^{2}\right)\right]
$$

dimana $\left|C_{k}\right|$ adalah jumlah pola latih pada kelas $\mathrm{Ck}$; m merupakan dimensi vektor pola masukan; dan wi adalah vektor bobot pada pola latih ke-i (Mao, 2000).

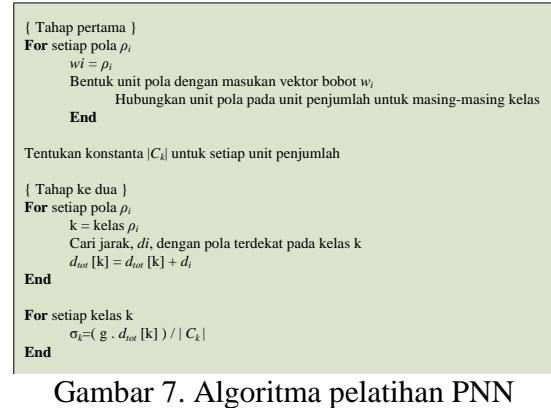

Algoritma pelatihan yang mengatur sendiri nilai $\sigma \mathrm{k}$ menyebabkan jaringan secara otomatis membentuk parameter tersebut untuk tiap kelas pada proses pelatihan tahap ke dua, seperti terlihat pada Gambar 7. Mekanisme yang sangat sederhana digunakan untuk membentuk nilai-nilai tersebut.

Parameter penghalus untuk suatu kelas adalah perkalian konstanta dengan rata-rata jarak minimum pola latih pada kelas yang sama. Maka, rata-rata jarak minimum antar vektor pola pada kelas $\mathrm{Ck}$ adalah :

$$
d_{\text {avg }}[k]=\frac{1}{\left|C_{k}\right|} \sum_{\rho_{i} \in C_{k}} d_{i}
$$

dimana di menotasikan jarak terdekat pola pi dengan pola yang lain pada kelas $\mathrm{Ck}$ sehingga parameter $\sigma \mathrm{k}$, untuk kelas $\mathrm{Ck}$ ditentukan dengan rumus :

$$
\sigma_{k}=g \cdot d_{\text {avg }}[k]
$$

Pemilihan konstanta g, agar jaringan memiliki akurasi pengklasifikasian yang tinggi diperoleh melalui percobaan, karena konstanta $g$ dipengaruhi oleh jumlah kelas, dimensi pola latih, dan jumlah anggota himpunan pelatihan.

Arsitektur PNN diperlihatkan pada Gambar 8. Jaringan tersebut memiliki empat lapisan yang terdiri atas, lapisan dengan $m$ unit masukan yang menerima vektor masukan $x$, lapisan unit-unit pola yang terhubung penuh dengan pola masukan, lapisan unitunit hasil penjumlahan yang terhubung penuh dengan tiap kelas dan lapisan keputusan untuk memilih nilai yang terbesar.

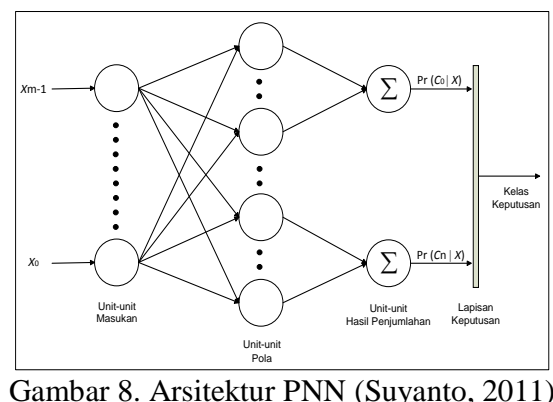

\section{Metodologi}

\subsection{Bahan Penelitian}

Bahan penelitian diperoleh dari pengambilan citra wajah sebanyak 10 orang dengan tiap orangnya 
masing-masing diambil 30 citra wajah, 15 citra wajah untuk pelatihan dan 15 citra wajah untuk pengujian. Setiap orang diambil citra wajah dari beberapa sudut, intensitas cahaya dan jarak yang berbeda. Semua proses pengambilan citra wajah tersebut dilakukan dalam ruangan dengan 3 jenis intensitas cahaya.

Proses pengambilan citra wajah pada penelitian ini diambil dengan 5 sudut pengambilan citra wajah, 3 perbedaan intensitas cahaya dan 2 jarak pengambilan citra wajah. Dengan proses pengambilan citra wajah tersebut untuk 1 orang didapatkan basisdata sebanyak 60 citra wajah.

Semua citra wajah tersebut diperoleh dari proses pengulangan pengambilan citra seperti terlihat pada Tabel 1. Sedangkan untuk proses pencocokan data citra wajah diperoleh dari citra wajah secara waktu nyata (realtime) dari akuisisi citra menggunakan webcam secara langsung.

Tabel 1. Faktor pengambilan citra wajah tiap orang

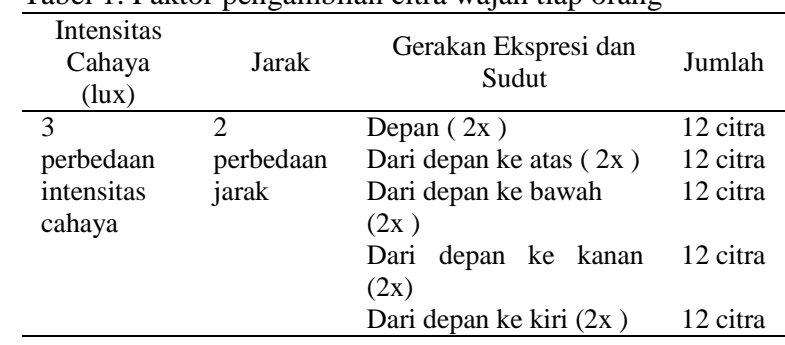

\subsection{Metode Pengumpulan Data}

Studi literatur merupakan metode pengumpulan data yang dilakukan untuk mendapatkan pengetahuan tentang sistem biometrika, pengenalan pola, pengenalan wajah, pengolahan citra, pusat massa (centroid), prapemrosesan, ekstraksi ciri dengan GLCM, PNN, fungsi aktivasi dan penentuan nilai ambang. Studi literatur juga diperlukan untuk mendapatkan informasi penelitian-penelitian sebelumnya tentang deteksi pengenalan wajah yang telah diterapkan. Berikut gambaran secara keseluruhan tentang sistem yang dibangun pada penelitian seperti ditunjukkan pada gambar 9 berikut.

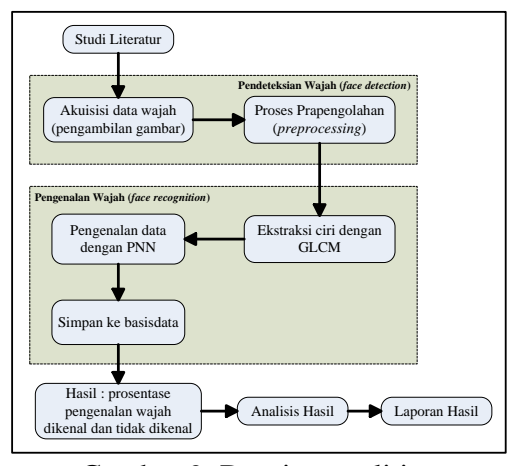

Gambar 9. Desain penelitian

\subsection{Perancangan}

Perancangan sistem secara keseluruhan dapat dijabarkan seperti tampak pada Gambar 10. Dalam proses perancangan ini terbagi dalam 2 tahap pengambilan data yaitu tahap pelatihan dan tahap pengujian.

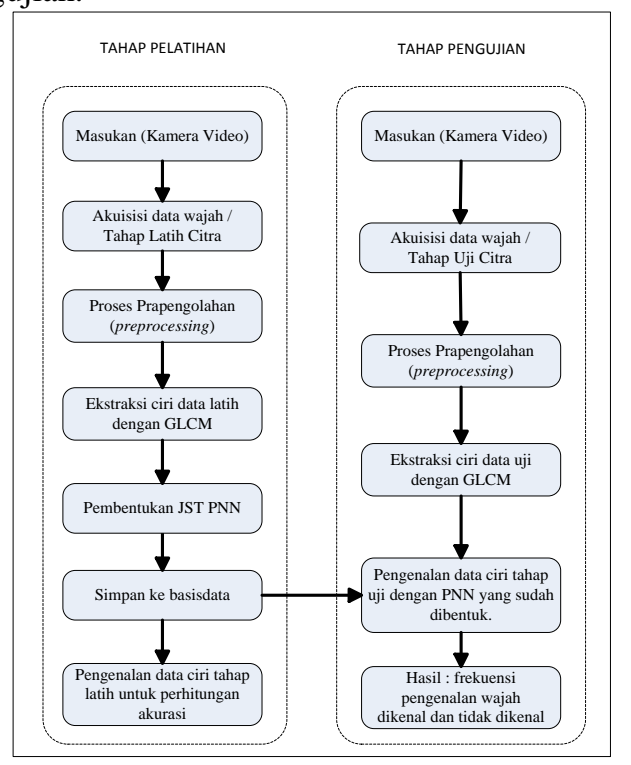

Gambar 10. Blok diagram sistem pengenalan wajah

Proses jalannya penelitian sebagai berikut :

a. Kamera video sebagai proses masukan pada pengambilan data citra wajah.

b. Akuisisi data wajah untuk proses pengambilan citra wajah (image capturing) kemudian hasil citra wajah disimpan dalam folder sesuai dengan nama pemilik citra wajah.

c. Tahap prapengolahan dilakukan normalisasi ukuran citra.

d. Ekstraksi ciri data tahap pelatihan dengan GLCM. Setelah memperoleh matriks kookurensi tersebut, dapat dihitung ciri statistik yang merepresentasikan citra yang diamati seperti terlihat prosesnya pada Gambar 11.

e. Pembentukan PNN dengan menguji data tahap pelatihan, hasilnya disimpan sebagai jaringan.

f. Simpan jaringan ke basisdata.

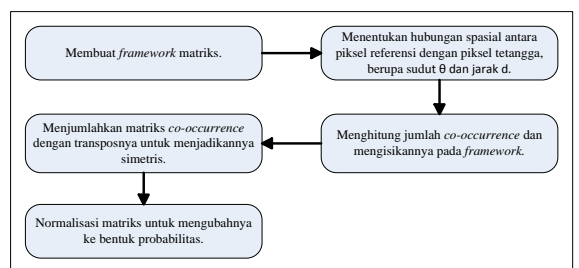

Gambar 11. Blok diagram ekstraksi ciri dengan GLCM

Sedangkan jalannya sistem blok pengambilan data pada tahap pengujian sebagai berikut:

a. Kamera video sebagai proses masukan dari sebuah sistem pengenalan wajah.

b. Akuisisi data wajah dilakukan proses pengambilan citra wajah (image capturing) yang dapat dilakukan secara tidak langsung maupun secara langsung / waktu nyata (realtime) menggunakan kamera video. 
c. Pada tahap prapengolahan dilakukan normalisasi ukuran citra.

d. Ekstraksi ciri data tahap pelatihan dengan GLCM.

e. Hasil keluaran berupa ciri GLCM pada tahap pengujian dimasukkan ke jaringan basisdata yang sudah dibentuk pada tahap pelatihan, untuk dicocokkan data citra wajahnya.

Arsitektur PNN seperti Gambar 12 terdiri atas 4 unit, yaitu unit masukan, unit pola, unit jumlah, dan unit keputusan.

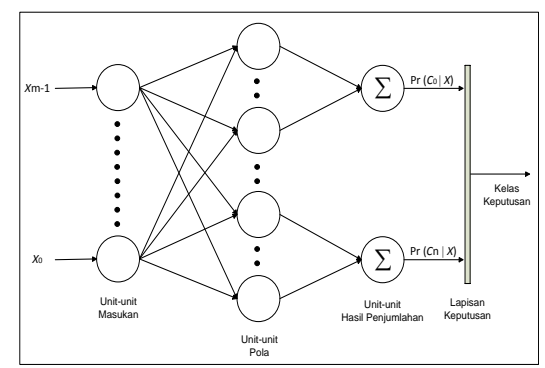

Gambar 12. Arsitektur PNN

Pada penelitian ini unit masukan yang terhubung ke semua unit pola berjumlah 16 , unit pola yang terhubung ke unit jumlah dari kelas yang sama dicoba dengan jumlah yang berbeda-beda yaitu pada jumlah neuron 300, 150, 100 dan 50, sedangkan unit yang terhubung ke unit keputusan berjumlah sama yaitu 10. Unit keputusan memutuskan kelas (label) dari masukan. Dalam prosesnya fungsi aktivasi yang digunakan adalah fungsi sigmoid biner. Fungsi sigmoid biner memiliki nilai pada range 0 sampai 1 . Fungsi ini sering digunakan untuk jaringan syaraf yang membutuhkan nilai keluaran yang terletak pada interval 0 sampai 1 . Fungsi ini bisa digunakan oleh jaringan syaraf yang nilai outputnya 0 atau 1 . Sedangkan algoritma pembelajarannya menggunakan metode pembelajaran terawasi karena keluaran yang diharapkan sudah dapat diketahui sebelumnya.

\subsection{Tahap Akuisisi Citra}

Citra wajah diperoleh secara langsung dengan menggunakan kamera video. Proses pengambilan citra wajah dilakukan sebanyak 5 kali dari 5 sudut yang berbeda, 3 kategori intensitas cahaya dan 2 jarak yang berbeda masing-masing diambil sebanyak 2 kali, sehingga akan menghasilkan 30 citra wajah untuk setiap orangnya. Data citra wajah sebanyak 30 terbagi menjadi 2 yaitu 15 untuk data pelatihan dan 15 untuk data pengujian. Proses pengambilan citra wajah pada tahap pelatihan menggunakan perangkat MATLAB, seperti terlihat pada Gambar 13.

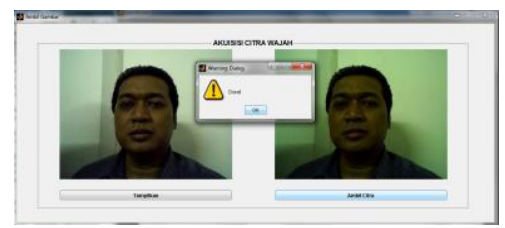

Gambar 13. Akuisisi citra wajah tahap latih

\subsection{Tahap Prapengolahan}

Pada tahap prapengolahan dilakukan normalisasi ukuran citra wajah, citra wajah yang diperoleh memiliki ukuran yang beragam, oleh karena itu harus diseragamkan sehingga memiliki ukuran yang sama. Tahapan prapengolahan meliputi menentukan pusat massa (centroid) yang diambil pada kotak mata kiri, kotak mata kanan dan kotak mulut, kemudian dilakukan pememotongan citra wajah dengan acuan pusat massa (centroid), memperbaiki kualitas citra masukkan agar memudahkan proses pengenalan tanpa menghilangkan informasi utamanya, memotong dan membuang bagian daerah selain wajah sehingga hanya bagian wajah saja yang diproses, mengubah ukuran citra menjadi 100 x 100 piksel, mengubah citra dari RGB ke dalam bentuk derajat keabuan dan normalisasi pencahayaan ketika pengambilan citra wajah. Hal ini semua perlu dilakukan untuk menjamin kelancaran pada proses berikutnya.

Berikut beberapa tahapan dalam prapemrosesan yang dilakukan seperti ditunjukkan pada Gambar 14 sebagai berikut:

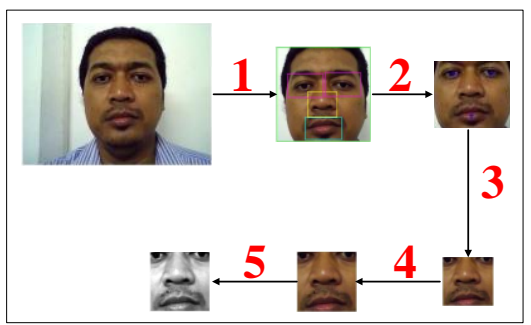

Gambar 14. Prapemrosesan citra wajah dari format RGB ke format keabuan

1. Citra wajah pengambilan dari kamera video ukuran $320 \times 240$ piksel dengan format RGB. Kemudian di segmentasi menggunakan fungsi detector wajah pada perangkat MATLAB dengan toolbox komputer vision.

2. Menentukan pusat masa (centroid) pada area mata kiri, mata kanan dan mulut dengan garis kotak.

3. Memotong dan membuang latar belakang dengan mengacu pusat masa (centroid) pada mata kiri, mata kanan dan mulut.

4. Merubah ukuran citra wajah agar seragam dengan ukuran $100 \times 100$ piksel.

5. Merubah citra wajah dari RGB ke dalam format keabuan.

\subsection{Tahap Ekstraksi Ciri}

Ekstraksi ciri diperoleh dengan menghitung hubungan ketetanggaan antara dua piksel pada jarak dan orientasi sudut tertentu. Dalam aplikasi ini ada 4 sudut dan dengan jarak spasial 1 yang digunakan dalam menentukan ciri pada citra wajah yaitu sudut $0^{0}$, sudut $45^{\circ}$, sudut $90^{\circ}$, dan sudut $135^{\circ}$. Setelah diperoleh matriks kookurensi tersebut, dapat dihitung 
ciri statistik yang merepresentasikan citra wajah yang diamati.

\subsection{Tahap Pendaftaran Citra}

Tahap pendaftaran citra wajah dilakukan berdasarkan kelompok intensitas cahaya dan jarak dengan mengekstraksi ciri-ciri dari beberapa citra wajah dan hasil yang diperoleh disimpan ke dalam basisdata. Pada tahap ini akan dilakukan pendaftaran 10 kali pada 3 intensitas cahaya yang berbeda dan di setiap intensitas cahaya dilakukan pada 2 jarak yang berbeda, sehingga akan didapatkan citra wajah sebanyak 60 untuk setiap orangnya.

\subsection{Tahap Keputusan}

Setelah pengujian selesai, maka diambil suatu kesimpulan untuk tingkat keakurasian pengenalan wajah berdasarkan posisi, intensitas cahaya dan jarak. Pada tahap ini diharapkan menghasilkan suatu keputusan berupa jawaban pengenalan wajah cocok atau tidak cocok.

\subsection{Algoritma Program}

Ekstraksi ciri bertujuan untuk menentukan ciriciri dari suatu citra wajah yang mampu membedakan antara citra wajah yang satu dengan citra wajah yang lain, serta dapat dilakukan suatu proses komputasi. Proses pencocokan adalah membandingkan ciri citra pengujian dengan ciri citra dalam basisdata. Hasil perbandingan ini berupa kesamaan nilai, semakin tinggi nilai kesamaannya semakin tinggi pula nilai kebenarannya. Adapun algoritma ekstraksi ciri yang akan dilakukan seperti Gambar 15 berikut :

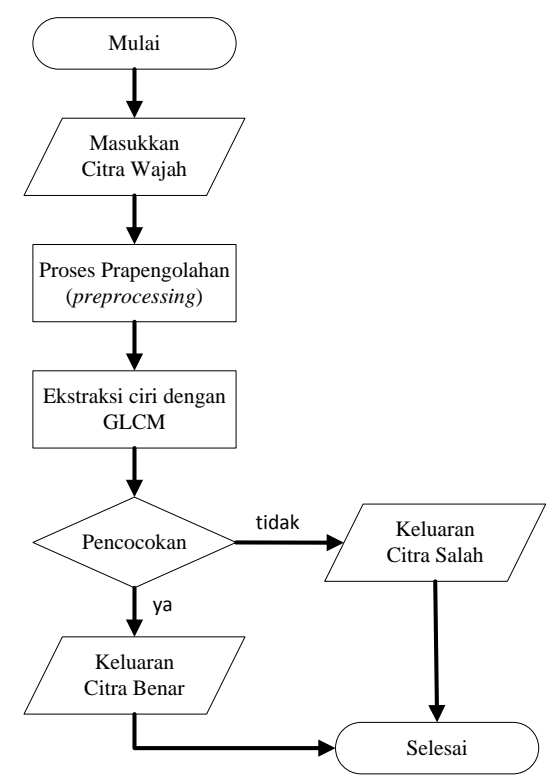

Gambar 15 Algoritma proses identifikasi citra wajah

Masukkan citra wajah berupa berkas jpg dan bmp dengan ukuran 320 x 240 piksel, proses prapengolahan (preprocessing) merupakan proses normalisasi ukuran citra wajah dengan metode centroid, ekstraksi ciri dengan GLCM merupakan proses penghitungan hubungan ketetanggaan antara dua piksel pada jarak dan orientasi sudut tertentu, pencocokan merupakan proses pengenalan data citra wajah pada tahap pelatihan dari basisdata dengan ciri data citra wajah tahap uji, hasil keluaran diharapkan menghasilkan suatu keputusan berupa jawaban pengenalan wajah cocok atau tidak cocok.

\section{Hasil dan Pembahasan}

\subsection{Simulasi Aplikasi}

Pada proses pengujian langsung maupun tidak langsung citra wajah yang digunakan diambil dari beberapa sudut diantaranya menghadap kekiri dengan sudut kemiringan kira-kira $65^{\circ}$, menghadap ke depan, menghadap ke kanan dengan sudut kemiringan kirakira $115^{\circ}$, menghadap ke bawah dengan sudut kirakira $65^{\circ}$ dan menghadap ke atas dengan sudut kirakira $115^{\circ}$, masing-masing dilakukan pada 2 jarak yang berbeda antara objek dengan kemera video yaitu pada jarak $30 \mathrm{~cm}$ dan $50 \mathrm{~cm}$, sedangkan posisi sudut yang dipakai seperti ditunjukkan pada Gambar 16 berikut :

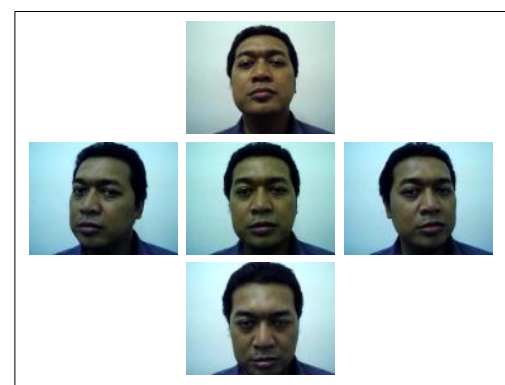

Gambar 16. Posisi citra wajah pada proses akuisisi citra

1. Simulasi proses akuisisi citra

Proses akuisisi citra wajah seperti ditunjukkan pada Gambar 17 sangat menentukan hasil pengenalan citra wajah pada proses pengenalan. Pada proses akuisisi citra diharapkan kedua mata kiri dan kanan serta mulut tidak pada kondisi tertutup, terutama pada saat posisi menghadap ke kiri, ke kanan, ke atas ataupun ke bawah. Apabila salah satu mata kiri, mata kanan atau mulut terhalang maka proses akuisisi wajah tidak bisa dilakukan, dan apabila posisi tersebut tetap diambil maka prosesnya mengalami kegagalan.

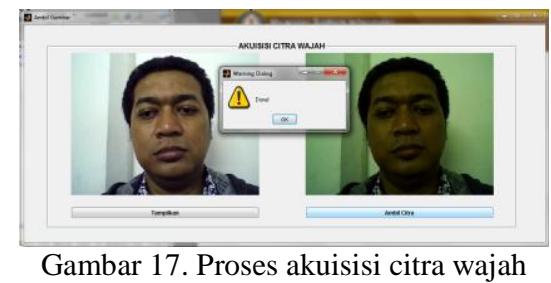

2. Simulasi proses pelatihan 
Simulasi program aplikasi pada tahap proses pelatihan seperti ditunjukkan pada Gambar 18 dan setelah dipilih tombol latih hasil dari proses pelatihan dapat ditunjukkan pada Gambar 19.

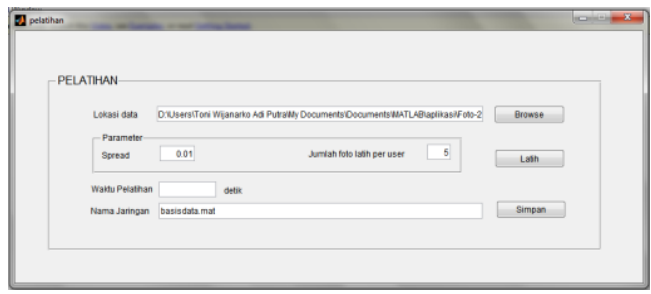

Gambar 18. Simulasi proses pelatihan

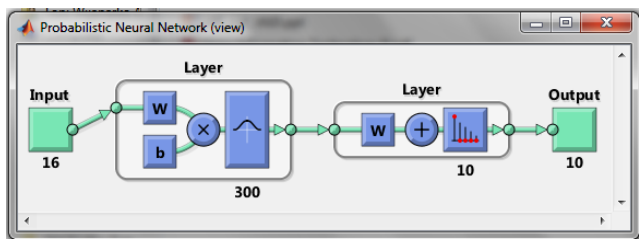

Gambar 19. Hasil proses pelatihan

3. Simulasi proses pengujian tidak langsung

Simulasi proses pengujian tidak langsung dengan hasil cocok dapat ditunjukkan pada Gambar 20.

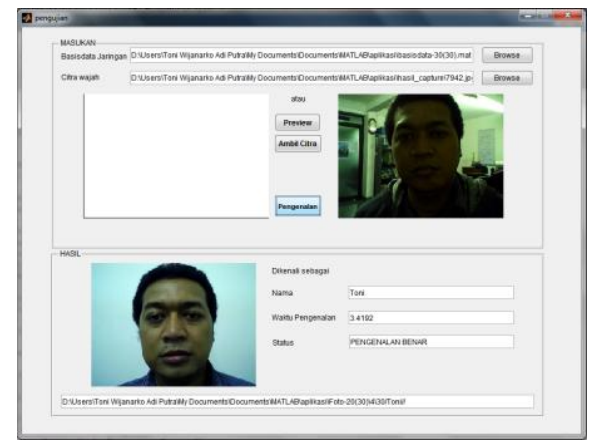

Gambar 20 Proses pengujian tidak langsung dengan hasil cocok

Sedangkan simulasi proses pengujian tidak langsung dengan hasil tidak cocok dapat ditunjukkan pada Gambar 21.

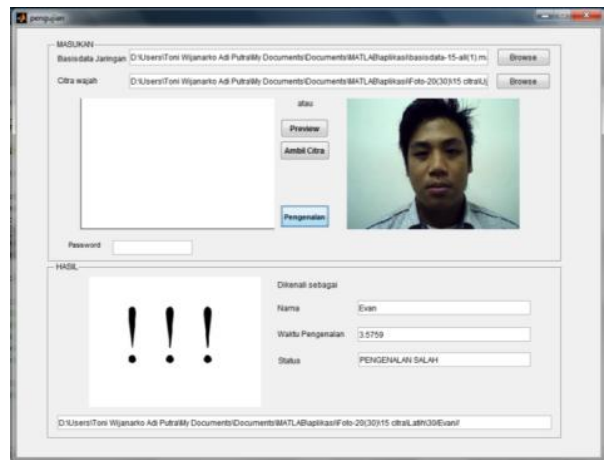

Gambar 21. Proses pengujian tidak langsung dengan hasil tidak cocok
4. Simulasi proses pengujian langsung

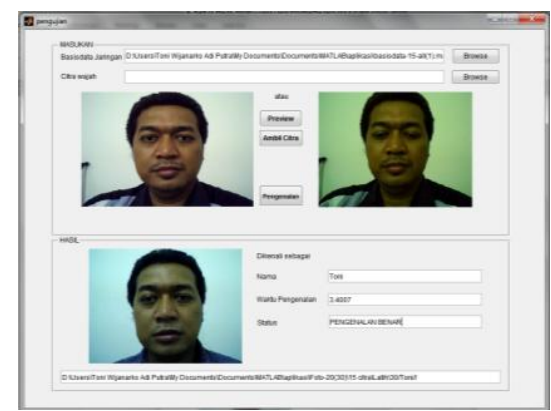

Gambar 22. Proses pengujian langsung dengan hasil cocok

Simulasi pada proses pengujian langsung dengan hasil cocok dapat ditunjukkan Gambar 22. Sedangkan simulasi pada proses pengujian langsung dengan hasil tidak cocok dapat ditunjukkan pada Gambar 23.

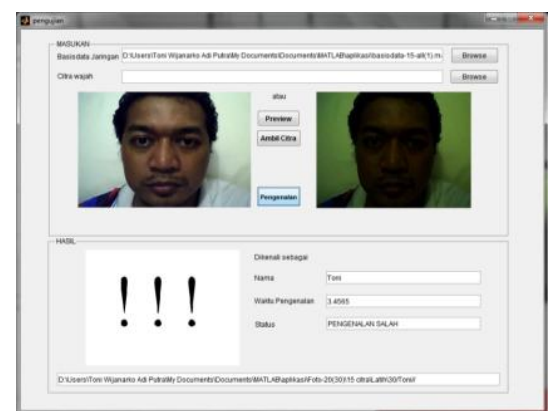

Gambar 23. Proses pengujian langsung dengan hasil tidak cocok

\subsection{Pengujian Sistem}

Pengujian sistem dilakukan untuk mengetahui kemampuan pengenalan citra wajah. Pengujian sistem dilakukan menggunakan data citra wajah dari tahap pelatihan dan menggunakan citra wajah yang diambil secara waktu nyata (realtime). Pengujian sistem menggunakan data citra wajah dilakukan pada 3 jenis intensitas cahaya dan dengan 2 jarak pengambilan citra wajah yang berbeda untuk setiap individunya. Berikut data penelitian yang diperoleh dari hasil pelatihan dan pengujian sistem dengan membandingkan berdasarkan intensitas cahaya, jarak dan posisi citra wajah.

1. Pengujian Jaringan Syarat Tiruan Probabilistik pada tahap pelatihan

Proses pengujian jaringan syarat tiruan probabilistik dilakukan pada tahap pelatihan dengan jumlah neuron sebanyak 300, 150, 100 dan 50. Hal ini dilakukan untuk menentukan nilai spread yang paling tepat untuk proses pembentukan jaringan. Nilai sebaran tingkat kesalahan (spread) pada tahap pengujian merupakan nilai rata-rata sebaran kesalahan.

Seperti ditunjukkan pada Tabel 2 bahwa pada pengujian di tahap pelatihan hasil terbaik pada spread dengan nilai 0,01 dengan jumlah neuron 300, 
150, 100 dan 50 yaitu dengan tingkat pengenalan mencapai $100 \%$, sedangkan pada spread 0,02, 0,03 dan 0,04 hasilnya kurang dari $100 \%$.

Tabel 2. Hasil pengujian tahap pelatihan berdasarkan jumlah neuron dan sebaran tingkat kesalahan (spread)

\begin{tabular}{ccccccccc}
\hline Spread & \multicolumn{2}{c}{0,01} & \multicolumn{2}{c}{0,02} & \multicolumn{2}{c}{0,03} & \multicolumn{2}{c}{0,04} \\
\hline Jumlah & Hasil & Waktu & Hasil & Waktu & Hasil & Waktu & Hasil & Waktu \\
Neuron & $(\%)$ & (detik) & $(\%)$ & (detik) & $(\%)$ & (detik) & $(\%)$ & (detik) \\
300 & 100 & 302 & 90 & 329,54 & 73 & 351,4 & 58,67 & 559,08 \\
150 & 100 & 154,03 & 98 & 157,05 & 82,67 & 173,54 & 73,33 & 277,84 \\
100 & 100 & 97,54 & 100 & 102,83 & 90 & 123,3 & 81 & 184,26 \\
50 & 100 & 44,98 & 100 & 50,48 & 96 & 81,2 & 80 & 90,7 \\
\hline
\end{tabular}

Dapat disimpulkan bahwa semakin kecil jumlah neuronnya maka nilai hasil tingkat pengenalannya semakin baik, sedangkan dengan nilai spread semakin besar maka hasil tingkat pengenalan semakin kecil.

\section{Pengujian sistem secara langsung dan tidak} langsung

Proses pengujian secara langsung maupun tidak langsung dipengaruhi oleh intensitas cahaya. Intensitas cahaya yang kurang dapat mempengaruhi pengenalan citra wajah baik pada tahap pelatihan maupun pada tahap pengenalan.

Hasil pengujian secara tidak langsung dapat ditunjukkan pada Tabel 10, sumber citra wajah pengujian secara tidak langsung berupa berkas yang sudah ditentukan posisinya dan bisa ditentukan hanya citra wajah dengan posisi baik yang dipakai.

Berdasarkan hasil pengujian pada jarak pengambilan citra wajah dengan jarak $30 \mathrm{~cm}$ yang ditunjukkan pada Tabel 3, bahwa pada proses ekstraksi ciri dari masing-masing sudut dan jarak piksel menghasilkan nilai yang berbeda dari masingmasing ciri sehingga memiliki tingkat pengenalan yang berbeda. Hal ini disebabkan oleh penggunaan sudut dan jarak piksel GLCM yang berbeda sehingga menghasilkan matriks GLCM yang berbeda pula.

Tabel 3 Tabel hasil pengujian jarak piksel tidak langsung masing-masing sudut terhadap tingkat pengenalan

\begin{tabular}{cccc}
\hline \multirow{3}{*}{ Sudut GLCM } & $\begin{array}{c}\text { Jarak 1 } \\
\text { piksel }\end{array}$ & $\begin{array}{c}\text { Jarak 2 } \\
\text { piksel }\end{array}$ & $\begin{array}{c}\text { Jarak 3 } \\
\text { piksel }\end{array}$ \\
\cline { 2 - 4 } & $\begin{array}{c}\text { Akurasi } \\
(\%)\end{array}$ & $\begin{array}{c}\text { Akurasi } \\
(\%)\end{array}$ & $\begin{array}{c}\text { Akurasi } \\
(\%)\end{array}$ \\
\hline $0^{0}$ & 48 & 64,67 & 64,67 \\
$45^{0}$ & 58 & 66,67 & 66,67 \\
$90^{0}$ & 54,67 & 70,67 & 57,33 \\
$135^{0}$ & 64 & 68,67 & 66 \\
$0^{0}+45^{0}+90^{\circ}+135^{\circ}$ & 93,33 & 86,67 & 86 \\
\hline
\end{tabular}

Pada matriks GLCM tunggal (hanya menggunakan salah satu sudut), tinggkat pengenalan tidak langsung tertinggi dengan jarak 1 piksel terdapat pada sudut $135^{\circ}$ dengan prosentase sebesar $64 \%$, jarak 2 piksel terdapat pada sudut $90^{\circ}$ dengan prosentase sebesar
$70,67 \%$, sedangkan jarak 3 piksel terdapat pada sudut $45^{\circ}$ dengan prosentase sebesar $66,67 \%$.

Pada matriks GLCM gabungan dengan lebih dari satu sudut $\left(0^{0}+45^{0}+90^{\circ}+135^{\circ}\right)$ didapatkan tingkat pengenalan secara tidak langsung paling tinggi untuk jarak 1 piksel, 2 piksel maupun 3 piksel dibandingkan dengan matriks GLCM tunggal, yaitu pada jarak 1 piksel sebesar 93,33\%, jarak 2 piksel sebesar $86,67 \%$ dan pada jarak 3 piksel sebesar $86 \%$.

Sedangkan pada pengenalan tidak langsung pengambilan citra wajah dengan jarak $50 \mathrm{~cm}$ diuji pada jarak 1 piksel dengan matriks GLCM gabungan lebih dari satu sudut $\left(0^{0}+45^{0}+90^{\circ}+135^{\circ}\right)$ menghasilkan tingkat pengenalan sebesar $30,67 \%$.

Pada proses pengenalan langsung citra wajah diuji pada jarak 1 piksel dengan matriks GLCM gabungan lebih dari satu sudut $\left(0^{0}+45^{0}+90^{0}+135^{\circ}\right)$ yang menghasilkan tingkat pengenalan sebesar $92 \%$. Proses pengujian ini didasarkan pada hasil tingkat pengenalan tidak langsung yang menghasilkan pengenalan tertinggi pada jarak 1 piksel dengan gabungan lebih dari satu sudut $\left(0^{0}+45^{0}+90^{0}+135^{0}\right)$ seperti ditunjukkan pada Tabel 3 diatas.

Dari hasil tersebut diatas menunjukkan bahwa semakin banyak matriks GLCM yang dibentuk, semakin banyak pula ciri-ciri yang dibandingkan sehingga peluang pada proses pengenalannya semakin baik dibandingkan dengan sudut tunggal yang hanya membentuk satu matriks GLCM.

Berdasarkan Tabel 3 didapatkan tingkat pengenalan yang berbeda untuk masing-masing jarak piksel GLCM. Hal ini dikarenakan penggunaan jarak piksel GLCM yang berbeda menghasilkan matriks GLCM yang berbeda sehingga ciri yang diekstraksi menghasilkan nilai yang berbeda satu sama lainnya. Untuk penggunaan jarak piksel GLCM dengan jarak tunggal diperoleh tingkat pengenalan secara tindak langsung tertinggi pada jarak 1 piksel yaitu sebesar $93,33 \%$, kemudian pada jarak 2 piksel sebesar $86,67 \%$ dan pada jarak 3 piksel sebesar $86 \%$.

\subsection{Pembahasan}

Pembahasan penelitian sistem pengenalan wajah ini meliputi akurasi tingkat pengenalan wajah diterima dan tingkat penolakan, pada intensitas cahaya, jarak tertentu serta waktu komputasi yang dibutuhkan selama proses pengenalan.

Tingkat akurasi pengenalan citra wajah didapatkan dari proses pengenalan wajah cocok yang dilakukan secara langsung dan tidak langsung. Akurasi pengenalan wajah cocok dapat dihitung dari total jumlah wajah cocok dibagi dengan jumlah wajah uji dikalikan $100 \%$.

Tingkat penolakan citra wajah merupakan citra wajah yang dinyatakan tidak cocok dengan ketentuan bila citra wajah dikenali sebagai orang lain. Nilai prosentasi dari tingkat penolakan citra wajah dapat dihitung dari jumlah total wajah ditolak dibagi dengan seluruh data kemudian dikalikan $100 \%$. 
Pada proses pelatihan data citra wajah yang digunakan hendaknya sangat diperhatikan karena bisa mempengaruhi hasil tingkat pengenalan. Hal ini merupakan bagian terpenting karena data citra wajah merupakan penentu dalam proses pengenalan. Citra wajah yang dijadikan sebagai basisdata hendaknya memperhatikan ukuran citra sama, latar belakang tidak terlalu rumit, jarak pengambilan citra wajah, dan cahaya. Citra wajah yang digunakan dalam basisdata dikelompokkan berdasarkan kategori jarak dan cahaya.

\section{Kesimpulan}

Penelitian ini dapat ditarik beberapa kesimpulan bahwa perbedaan cahaya yang tidak terlalu banyak tidak mempengaruhi hasil pengenalan. Jarak antara objek citra wajah dengan kamera juga sangat berpengaruh dimana semakin jauh jarak antara objek dengan kemera maka prosentase tingkat pengenalannya semakin berkurang. Hal ini dibuktikan dengan hasil pengenalan pada jarak $30 \mathrm{~cm}$ dengan hasil 93,33\% dan pada jarak $50 \mathrm{~cm}$ dengan hasil 30,67\%.

Tahap prapengolahan dilakukan dengan merubah citra RGB ke dalam bentuk derajat keabuan dengan proses segmentasi menggunakan centroid.

Pengujian sudut gabungan matriks GLCM yang dibentuk lebih banyak, dibandingkan dengan pengujian dengan sudut tunggal sehingga peluang pada proses pengenalannya semakin baik. Penggunaan semua sudut terbukti memiliki tingkat pengenalan yang tinggi, baik itu pengujian secara tidak langsung maupun pengujian secara langsung dibandingkan dengan penggunaan sudut secara tunggal.

Pengujian terhadap penggunaan jarak piksel GLCM dengan jarak tunggal diperoleh tingkat pengenalan secara tindak langsung tertinggi pada jarak 1 piksel yaitu sebesar 93,33\%, kemudian pada jarak 2 piksel sebesar $86,67 \%$ dan pada jarak 3 piksel sebesar $86 \%$, sedangkan pengenalan secara langsung pada jarak 1 piksel gabungan dengan lebih dari satu sudut $(00+450+900+1350)$ sebesar $92 \%$.

Pengujian terhadap jarak dan sudut GLCM pada 10 citra wajah dengan 5 posisi, masing-masing pada 3 intensitas cahaya yang berbeda dengan hasil 150 citra wajah yang menghasilkan akurasi tingkat pengenalan tidak langsung tertinggi pada sudut $(00+450+900+1350)$ dan pada jarak 1 piksel yaitu sebesar 93,33\%, sedangkan akurasi tingkat pengenalan secara langsung sebesar $92 \%$.

\section{Daftar Pustaka}

Albregtsen, F., 2008. Statistical Texture Measures Computed from Gray Level Coocurrence Matrices, Image Processing Laboratory, Department of Informatics, University of Oslo.
Araghi, L.F., Khaloozade, H., dan Arvan, M.R., 2009. Ship Identification Using Probabilistic Neural Networks (PNN). Proceedings of the International Multiconference of Engineers and Computer Scientists, Vol II IMECS, March 1820, Hong Kong.

Bayu, S., Hedriawan, A., dan Susetyoko, R, 2009. Penerapan Face Recognition Dengan Metode Eigenface dalam Intelligent Home Security, skripsi, Politeknik Elektronika Negeri Surabaya Institut Teknologi Sepuluh Nopember (ITS) Surabaya.

Emary, I.M.M., dan Ramakrishnan, S., 2008. On the Application of Various Probabilistic Neural Networks in Solving Different Pattern Classification Problems, World Applied Sciences Journal 4 (6), 772-780.

Falasev, R.S., Hidayatno, A., dan Isnanto, R., 2011. Pengenalan Sidik Jari Manusia Dengan Matriks Kookurensi Aras Keabuan (Gray Level CoOcurrence Matrix), Makalah Tugas Akhir Universitas Diponegoro. Semarang.

Fatta, H.A., 2009. Rekayasa Sistem Pengenalan Wajah, Andi Offset, Yogyakarta.

Febrianto, Y., 2012. Pengklasifikasian Kualitas Keramik Berdasarkan Ekstraksi Fitur Tekstur Statistik, Jurusan Teknik Informatika Fakultas Teknologi Industri Universitas Gunadarma.

Gill, G.S., dan Sohal, J.S., 2008. Battlefield Decision Making : A Neural Network Approach, Journal of Theoretical and Applied Information Technology, Vol.4, No.8, 697-699.

Gorodnichy, D.O., 2004. Introduction to the First IEEE Workshop on Face Processing in Video, Conference Publications, 27 - 02 Juni, 61.

Harmoko, S.A., Kusumoputro, B., Rangkuti, M., 2004. Ekstraksi Ciri Gray Level Co-Occurrence Matrix Dan Probabilistic Neural Network Untuk Pengenalan Cacat Pengelasan, Departemen Fisika FMIPA, Universitas Indonesia, Fakultas Ilmu Komputer, Universitas Indonesia.

Heriana, O., Widodo, T.S., Soesanti, I., dan Tjokronagoro, M., 2011. Klasifikasi Citra Kanker Payudara dengan Menggunakan Algoritma Fuzzy C means. Jurnal Elektronika, Universitas Gajah Mada Yogyakarta, Vol.11, No.2.

Jain, A., Hong, L., and Pankanti, S., 2000. Biometric Identification, Communications of The ACM, Vol 43, No 2, 91-99.

Kadir, A., Nugroho, L.E., Susanto, A., dan Santosa, P.I., 2011. Neural Network Application on Foliage Plant Identification, International Journal of Computer Application (0975-8887), Vol.29. No.9, 15-22.

Khrisna, D.A., Hidayatno, A., dan Isnanto, R., 2011. Identifikasi Objek Berdasarkan Bentuk dan Ukuran, Makalah Tugas Akhir Universitas Diponegoro, Semarang. 
Kulkarni, A.H., dan Patil, S.B., 2012. Automated Garment identification and defect detection model based on Texture Features and PNN, International Journal of Latest Trends in Engineering and Technology, Vol. 1, Issue 2 July.

Kung, S.Y., 1999. Synergistic Modeling and Applications of Hierarchical Fuzzy Neural Networks, Proceedings of the IEEE Vol. 87 No.9, 1550-1574.

Limanto, S, dan Arief, T.D., 2005. Studi Awal Aplikasi Teori Fuzzy Set Pada Perusahaan Readymix Concrete Dalam Memilih Pemasok Material Beton, Civil Engineering Dimension, Vol.7, No.1, 46-56, March 2005.

Maheshwary, P., dan Sricastava, N., 2009. Prototype System for Retrieval of Remote Sensing Images based on Color Moment and Gray Level CoOccurrence Matrix, IJCSI International Journal of Computer Science Issues, Vol. 3.

Maltoni, D., Maio, D., Jain, A.K., dan Prabhakar,S., 2009. Handbook of Fingerprint Recognition, Second Edition, Springer-Verlag London Limited.

Mao, K.Z., Tan, K.C., dan Ser, W., 2000. Probabilistic Neural-Network Structure Determination for Patten Classification, IEEE Transactions on neural networks, Vol. 11 No.4.

Nie, F., Gao, C., Guo, Y., dan Gan, M., 2011. Twodimensional minimum local cross-entropy thresholding based on co-occurrence matrix, Computer and Electrical Engineering 37, 757767.

Prasetyo, E., 2011. Pengolahan Citra Digital dan Aplikasinya dengan MALTAB, Andi, Yogyakarta.

Purnomo, M.H., dan Muntasa, A., 2010. Konsep Pengolahan Citra Digital dan Ekstraksi Fitur, Graha Ilmu, Yogyakarta.
Putra, D., 2009. Sistem Biometrika. Konsep Dasar, Teknik Analisis Citra dan Tahapan Membangun Aplikasi Sistem Biometrika, Andi Offset, Yogyakarta.

Putra, D., 2010. Pengolahan Citra Digital. Andi Offset. Yogyakarta.

Santhanam, T., dan Radhika, S., 2011. Probabilistic Neural Network - A Better Solution for Noise Classification, Journal of Theoretical and Applied Information Technology, Vol. 27 No.1, 39-42.

Sumarno, L., 2007. Pengenalan Huruf Tulisan Tangan Berderau dan Terskala Berbasis Ekstraksi Ciri DCT dengan Menggunakan Jaringan Syaraf Probabilistik, SIGMA, Vol. 10, No. 2, Juli, 185197.

Suyanto, S.T., 2011. Artificial Intelligence, Informatika. Bandung.

Tori, E.K., 2012. Analisis Pengaruh Intensitas Cahaya pada Pengepakan Bando di Mesin Injection CV. Prima Lestari, Program Studi Teknik Industri, Fakultas Teknik Universitas Mercu Buana Jakarta.

Tran, D.H., Ng, A.W.M., Perera, B.J.C., Burn, S., dan Davis, P., 2006. Application of probabilistic neural networks in modeling structural deterioration of stormwater pipes, Urban Water Journal, Vol.3, No 3, September 2006, 175-184.

Vinitha, K.V., 2009. Face Recognition using Probabilistic Neural Networks, Conference Publications, 9 - 11 Desember, 1388-1393.

Wibowo, A., Ajie, S., Hidayatno, Achmad, Rizal, I., 2011. Analisis Deteksi Tepi Untuk Mengidentifikasi Pola Daun, Undergraduate thesis, Teknik Elektro Universitas Diponegoro.

Zhou, S., Krueger, V., dan Chellappa, R., 2003. Probabilistic recognition of human faces from video, Computer Vision and Image Understanding 91, 214-245. 